\title{
Methanothrix soehngenii gen. nov. sp. nov., a New Acetotrophic Non-hydrogen-oxidizing Methane Bacterium
}

\author{
Beat A. Huser*, Karl Wuhrmann, and Alexander J. B. Zehnder \\ Swiss Federal Institute of Technology, Zürich, and Federal Institute for Water Resources and Water Pollution Control, \\ Ueberlandstrasse 133, CH-8600 Dübendorf, Switzerland
}

\begin{abstract}
A new genus of methanogenic bacteria is described, which was isolated from a mesophilic sewage digester. It is most probably the filamentous bacterium, earlier referred to as Methanobacterium soehngenii, "fat rod" or "acetate organism". The single non-motile, non-sporeforming cells are rod-shaped $(0.8 \times 2 \mu \mathrm{m})$ and are normally combined end to end in long filaments, surrounded by a sheath-like structure. The filaments form characteristic bundles. Methanothrix soehngenii decarboxylates acetate, yielding methane and carbon dioxide. Other methanogenic substrates $\left(\mathrm{H}_{2}-\mathrm{CO}_{2}\right.$, formate, methanol, methylamines) are not used for growth or methane formation. Formate is split into hydrogen and carbon dioxide. The temperature optimum for growth and methane formation is $37^{\circ} \mathrm{C}$ and the optimal $\mathrm{pH}$ range is $7.4-$ 7.8. Sulfide and ammonia serve as sulfur and nitrogen source respectively. Oxygen completely inhibits growth and methane formation, but the bacteria do not loose their viability when exposed to high oxygen concentrations. $100 \mathrm{mg} / \mathrm{l}$ vancomycin showed no inhibition of growth and methanogenesis. No growth and methane formation was observed in the presence of: 2-bromoethanesulfonic acid, viologen dyes, chloroform, and $\mathrm{KCN}$. The bacterium has a growth yield on acetate of $1.1-1.4 \mathrm{~g}$ biomass per mol acetate. The apparent " $K_{s}$ " of the acetate conversion system to methane and carbon dioxide is $0.7 \mathrm{mmol} / 1$. The DNA base composition is $51.9 \mathrm{~mol} \%$ guanine plus cytosine. The name Methanothrix is proposed for this new genus of filamentous methane bacterium. The type species, Methanothrix soehngenii sp. nov., is named in honor of N. L. Söhngen.
\end{abstract}

Key words: Methane bacterium - Acetate decarboxylation - Methanothrix soehngenii

Acetate is one of the extracellular key intermediates in the anaerobic decomposition of organic material (Buswell and Hatfield 1936; Mah et al. 1976; Smith 1966) and serves as the principal substrate for methanogenesis. It is the precursor of $60-85 \%$ of the methane produced in anaerobic natural environments like sediments (Belyaev et al. 1975; Cappenberg and Prins 1974; Winfrey and Zeikus 1979), flooded soils (Takai 1970), paddy fields (Takai et al. 1963) and in manmade habitats like sewage digesters (Jeris and McCarty 1965;

* Present address: University of Otago, Dept. of Microbiology, Dunedin, New Zealand

Offprint requests to: A. J. B. Zehnder
Smith and Mah 1966; van den Berg et al. 1976) or biogas plants (Mackie and Bryant 1981; Mountfort and Asher 1978). Besides the quantitative, the qualitative importance of acetate was pointed out by Kaspar and Wuhrmann (1978) and van den Berg et al. (1976). Their experimental data indicated that acetate decarboxylation may be the ratelimiting step in the breakdown of dissolved organic matter.

Acetate was the first methanogenic substrate identified (Hoppe-Seyler 1876). However it took several decades until the first organism capable of converting acetate to methane (Methanosarcina barkeri) was isolated in pure culture (Schnellen 1947). In this report we describe a filamentous methane bacterium, Methanothrix soehngenii unable to oxidize hydrogen, using exclusively acetate for growth and methanogenesis. The isolation procedure and a preliminary characterization of this "acetate organism" has already been published earlier (Zehnder et al. 1980). In this paper we apprise the optimal growth conditions (medium composition, temperature, $\mathrm{pH}$ ), kinetic data, the effect of some antibiotics and inhibitors on growth and methanogenesis, and the inability of several compounds to serve as a methanogenic substrate or cosubstrate (in presence of acetate). Further observations necessary for the characterization of the new species and its possibie taxonomic position $(G+C$ value, cell wall and lipid composition etc.) have been gathered.

\section{Materials and Methods}

\section{Source of the Organism}

Strains of Methanothrix soehngenii were isolated from samples of digested sludge from the sewage treatment plant in Opfikon near Zurich and from the Madison Metropolitan sewage treatment plant (Wisconsin, USA). In the following, only the Opfikon strain is considered.

\section{Anaerobic Procedures}

The strict anaerobic methods developed by Hungate (1950) and modified by Bryant (1972) and Balch and Wolfe (1976) were used throughout these investigations, including a fretertype anaerobic chamber (Coy, Lab. Products Inc., Ann Arbor, Michigan). Additions and withdrawals of all samples were made with sterile outgassed syringes and hypodermic needles. Gas samples from the headspace were removed with a Pressure Lok Syringe (Precisions sampling Co,, Baton Rouge, LA, USA). 


\section{Media and Growth Conditions}

Methanothrix soehngenii was routinely cultivated in a mineral salt (MS)-medium with acetate as sole energy source. The following stock solutions were used (grams per liter of distilled water): (A) $\mathrm{KH}_{2} \mathrm{PO}_{4}, 27.2$; (B) $\mathrm{Na}_{2} \mathrm{HPO}_{4} \times 2 \mathrm{H}_{2} \mathrm{O}$, 35.6; (C, mineral salt solution) $\mathrm{NH}_{4} \mathrm{Cl}, 60 ; \mathrm{NaCl}, 60 ; \mathrm{CaCl}_{2}$ $\times 2 \mathrm{H}_{2} \mathrm{O}, 22 ; \mathrm{MgCl}_{2} \times 6 \mathrm{H}_{2} \mathrm{O}, 20$; (D) $\mathrm{NaHCO}_{3}, 80$; (E, trace metal solution) according to Zehnder et al. (1980); (F) ethylendiaminotetracetate, 1 ; $(\mathrm{G}$, vitamin solution) according to Wolin et al. (1963); $(\mathrm{H})$ resazurin, 1. One liter of the MS-medium was prepared with $8 \mathrm{ml}$ of solution A, $24 \mathrm{ml}$ of solution $B, 1 \mathrm{ml}$ each of $F$ and $H$, and made up with distilled water and $6.8 \mathrm{~g}$ sodium acetate $(50 \mathrm{mmol} / \mathrm{l})$ to $940 \mathrm{ml}$. This solution was boiled for $5 \mathrm{~min}$ in a waterbath and finally autoclaved $\left(20 \mathrm{~min}, 121 \% \mathrm{C}\right.$ ) under an atmosphere of $80 \% \mathrm{~N}_{2}$ $-20 \% \mathrm{CO}_{2}$. After cooling, $1 \mathrm{ml}$ of trace metal solution $\mathrm{E}$, $1 \mathrm{ml}$ of vitamin solution $\mathrm{G}, 50 \mathrm{ml}$ of solution $\mathrm{D}, 5 \mathrm{ml}$ of mineral solution $C$ and $100 \mathrm{mg}$ vancomycin dissolved in $1 \mathrm{ml}$ distilled $\mathrm{H}_{2} \mathrm{O}$ were added aseptically to the autoclaved medium using a $0.2 \mu \mathrm{m}$ disposable filter assembly (Gelman Sciences, Ann Arbor, MI, USA). Just before inoculation, $5 \mathrm{ml}$ of a freshly prepared reducing solution, containing $0.24 \mathrm{~g}$ $\mathrm{Na}_{2} \mathrm{~S} \times 9 \mathrm{H}_{2} \mathrm{O}$ and $0.03 \mathrm{~g} \mathrm{Na}_{2} \mathrm{~S}_{2} \mathrm{O}_{4}$ were added in the same way. After inoculation, the medium was gassed again and the gas phase was brought to $152 \mathrm{kN} / \mathrm{m}^{2}$. Unless stated otherwise, the gas mixture used was $80 \% \mathrm{~N}_{2}-20 \% \mathrm{CO}_{2}$. The final $\mathrm{pH}$ value of the medium was 7.3-7.4. Any further supplements of the medium were added prior to the reduction solution.

Cells were cultivated in serum vials $(35.5$ or $118 \mathrm{ml}$ ) closed with black lip butyl rubber stoppers and sealed with an aluminium seal (Balch and Wolfe 1976), or in 1 liter serum bottles with serum caps (diameter $35 \mathrm{~mm}$ ). Incubations were performed at $37^{\circ} \mathrm{C}$ in the dark without shaking. All individual experiments were done at least in duplicates, and the results reported were averaged.

\section{Mass Cultivation}

$M$. soehngenii was mass-cultured in 201 carboys (inoculum $1 \%, \mathrm{vol} / \mathrm{vol}$ ) on mineral salt medium with $100 \mathrm{mM}$ acetate. At the end of the logarithmic growth phase $(2-3$ months $)$ the cells were harvested with a continuously fed centrifuge (Christ, Zeta 20, rotor No. 8530) under anaerobic conditions $\left(\mathrm{N}_{2}, 12,000 \mathrm{rpm}, 100 \mathrm{ml} / \mathrm{min}\right)$. Cells were frozen in liquid nitrogen and were either lyophilized or stored at $-20^{\circ} \mathrm{C}$ for further use. The biomass amounted to $25 \mathrm{~g}$ wet weight $(2.2 \mathrm{~g}$ dry weight).

\section{Purity Tests}

Cultures were routinely checked for purity by examination of wet mounts using phase microscopy, fluorescence microscopy (with a $420 \mathrm{~nm}$-filter), and by dilutions in the following complex media: 1. Thioglycollate-medium (Difco), 2. ACmedium (Difco), 3. CMC-medium (Holdemann and Moore 1972). The inoculated tubes were incubated for $2-3$ months at $37^{\circ} \mathrm{C}$. $M$. soehngenii showed no growth in these media. Contaminations were identified by visual and microscopic examination. Tubes inoculated with filter sterilized $(0.2 \mu \mathrm{m})$ or heat treated $\left(90^{\circ} \mathrm{C}, 10 \mathrm{~min}\right)$ cultures served as controls. The number of contaminants were calculated using the most probable number technique (MPN).

\section{Substrate Utilization}

Tests for the utilization of various compounds as substrates for growth and/or methane formation were performed in $35.5 \mathrm{ml}$ serum vials containing either $20 \mathrm{ml}$ MS-medium (acetate $=10 \mathrm{mmol} / 1$ ) or $20 \mathrm{ml}$ MS-medium without acetate. The compounds assayed were added to a final concentration of $10 \mathrm{mmol} / \mathrm{l}$ each. Duplicates were inoculated $(50 \%$, vol $/ \mathrm{vol})$, and the formation of methane determined after 10 weeks of incubation. Vials with inactive, heat treated cells $\left(90^{\circ} \mathrm{C}\right.$, $10 \mathrm{~min}$ ) served as controls.

\section{Effect of Temperature and $p H$}

Cultures in MS-medium (inoculum $0.1 \%$ vol $/$ vol) were incubated at the appropriate temperatures $(3,10,15,22,25$, $30,33,37,40,50,55$, and $65^{\circ} \mathrm{C}$ ) and assayed weekly for methane. A specific methane production rate constant $\left(\mu_{\mathrm{CH}_{4}}\right)$ was calculated for the exponential growth phase. After 18 weeks, all of the bottles with only little or without growth and methane formation were placed for an additional 6 weeks at $37^{\circ} \mathrm{C}$ to determine whether the effect of these temperatures had actually been lethal to the organism. Cultures which did not return to active growth were considered dead.

To determine the optimal $\mathrm{pH}$, experiments were performed in $35.5 \mathrm{ml}$ serum vials with $20 \mathrm{ml}$ of a bicarbonate-free MS-medium with $2 \mathrm{mM}$ acetate. The desired $\mathrm{pH}$ was controlled with a $20 \mathrm{mM}$ phosphate-buffer. The acetate concentration was kept low to reduce $\mathrm{pH}$-changes due to bicarbonate formation from acetate. Triplicates were incubated for $4-8$ weeks, and the methane production rate was determined.

\section{Labeling Experiments}

Experiments with $\left[{ }^{14} \mathrm{C}\right]$-radiotracers were performed as described by Zehnder et al. (1980). ${ }^{14} \mathrm{CH}_{4}$ and ${ }^{14} \mathrm{CO}_{2}$ in the headspace were measured according to the method of Zehnder et al. (1979), using a liquid scintillation counter.

Studies on the metabolism of formate were done in $35.5 \mathrm{ml}$ vials containing $20 \mathrm{ml} \mathrm{MS}-$ medium in which acetate was replaced by formate. $\left[{ }^{14} \mathrm{C}\right]$-formate (specific activity $4.8 \mu \mathrm{Ci} / \mathrm{mmol}$ ), methanol and hypophosphite were added from anaerobic stock solutions. For every experimental condition several replicates $(4-6)$ were inoculated $(10 \%$, $\mathrm{vol} / \mathrm{vol}$ ) and sacrificed at different incubation times by acidifying them to $\mathrm{pH} 1$ with $\mathrm{HCl}$ conc. Subsequently the headspace was assayed for $\mathrm{CH}_{4}, \mathrm{CO}_{2}$ and $\mathrm{H}_{2}$ and the liquid for formate, methanol and acetate. Inactive, heat treated $\left(90^{\circ} \mathrm{C}, 10 \mathrm{~min}\right)$ cultures served as controls.

For the kinetic experiments varying acetate concentrations $(0.1,0.2,0.5,1,2,5,10$ and $50 \mathrm{mmol} / 1$; sodium $\left[2-{ }^{14} \mathrm{C}\right]$-acetate with a specific activity of $3-70 \mu \mathrm{Ci} / \mathrm{mmol}$ ) were inoculated $(20 \%, \mathrm{vol} / \mathrm{vol})$. During incubation the vials were assayed for methane and acetate and the corresponding metabolic rates $\left(v_{\mathrm{CH}_{4}}\right.$, methane production rate; $v_{\mathrm{Ac}^{\prime}}$ acetate consumption rate) calculated.

\section{Inhibitor Studies}

Anaer obic solutions of the tested inhibitors were injected into the culture vessels $24 \mathrm{~h}$ prior to inoculation $(20 \%$, vol $/ \mathrm{vol})$. After incubation for 6 weeks the methane produced was measured. An untreated culture served as a control. 


\section{Antibiotics}

The effect of several antibiotics on the growth of $M$. soehngenii was tested by inoculating $(20 \%$ vol/vol) MSmedium which contained the antibiotics in the desired final concentration. The increase in dry weight was determined after 4 weeks of incubation.

\section{Growth Yield and Specific Metabolic Rates}

Cell yields were determined at the end of growth in $1250 \mathrm{ml}$ serum bottles containing $500 \mathrm{ml}$ MS-medium (acetate = $100 \mathrm{mmol} / \mathrm{l})$. Inocula of $0.5 \%$ (vol $/ \mathrm{vol}$ ) were used for all growth yield determinations. Following incubation, the cultures were sacrificed by adding $\mathrm{HCl}$ conc. to $\mathrm{pH}$ 3. Cell lysis was not observed at this $\mathrm{pH}$ (protein content of acidified cell suspensions not higher than controls at a neutral $\mathrm{pH}$ ). The dry weight was determined by filtering triplicate aliquots $(20 \mathrm{ml})$ with preweighed membrane filters $(0.45 \mu \mathrm{m}$, Sartorius Nr. 11306, Göttingen) and drying them to constant weight for $24 \mathrm{~h}$ at $80^{\circ} \mathrm{C}$. Cultures incubated with 2-bromoethanesulfonic acid (2-BES, $100 \mu \mathrm{mol} / 1)$, showing no growth and methane formation, served as controls. The specific methane production rate $\left(k_{\mathrm{CH}_{4}}\right)$ and the specific acetate consumption rate $\left(k_{\mathrm{Ac}}\right)$ are given as $\mathrm{mmol}$ methane (produced) $\times \mathrm{g}^{-1}$ (dry weight) $\times \mathrm{h}^{-1}$ and mmol acetate (consumed) $\times \mathrm{g}^{-1}$ (dry weight $\times \mathrm{h}^{-1}$ respectively. They were determined in batchcultures (500 ml MS-medium, temperature $37^{\circ} \mathrm{C}, \mathrm{pH} 7.5-$ 7.7).

\section{DNA Base Composition}

Cells were disrupted by passage through a French pressure cell at $140,000 \mathrm{kN} / \mathrm{m}^{2}$ (treatment with lysozyme and/or sodium dodecyl sulfate did not cause cell lysis). Isolation and purification of the DNA proceeded as described by Stackebrandt and Kandler (1979).

The guanine plus cytosine $(\mathrm{G}+\mathrm{C})$ content of the deoxyribonucleic acid was determined from duplicate preparations by thermal denaturation $\left(T_{m}\right.$-method), using an automatic recording spectrophotometer (Gilford Instrument Laboratories, Ind., Oberlin, OH, USA).

\section{Analytic Procedures}

Methane and acetate were detected by gaschromatography as described by Zehnder et al. (1980). Hydrogen was determined by a two-column gas chromatograph (Poropak Q) connected to a thermoconductivity detector (Gow Mac Instruments Co. Ltd., Shannon, Ireland).

\section{Chemicals and Radioisotopes}

All chemicals used were of the highest purity available (analytical grade). Coenzyme $\mathrm{M}$ as mercaptoethanesulfonic acid sodium salt was purchased from Pierce Chemical Co., Rockford, Ill. Resazurin, methylviologen and benzylviologen were obtained from BDH Chemicals Ltd., Poole. Vancomycin was a gift of the Swiss Serum and Vaccine Institute, Bern. The other antibiotics and inhibitors were supplied as follows: Novobiocin and valinomycin from Boehringer, Mannheim; 2-bromoethanesulfonic acid from Fluka AG, Buchs; penicillin-G from E. Lilly GmbH; D-cycloserine from
Hoffmann-La Roche; dihydrostreptomycin from Sigma Chemical Co.; ampicillin from Bayer AG, Leverkusen.

The following radiochemicals were obtained from New England Nuclear Corp., Boston, Mass.: Sodium $\left[{ }^{14} \mathrm{C}\right]-$ formate $(2.8 \mathrm{mCi} / \mathrm{mmol})$ and sodium $\left[2-{ }^{14} \mathrm{C}\right]$-acetate $(3.0 \mathrm{mCi} / \mathrm{mmol})$.

\section{Results}

\section{Morphology}

The non-motile organism shows a Gram-negative reaction. No spores have been observed. Methanothrix soehngenii forms verly long and flexible filaments which tend to aggregate in characteristic bundles (Fig. 1). Intensive shaking or stirring breaks the filaments into smaller pieces. The rodshaped cells $(0.8 \times 2 \mu \mathrm{m})$ have flat ends and are arranged end to end in the filaments.

\section{Stoichiometry of the Conversion of Acetate to Methane}

Acetate served as sole source of energy and organic carbon in a MS-medium. Hence, growth of $M$. soehngenii is chemoorganotrophic. A typical course of methane production and acetate consumption over an entire growth period of a batch culture in an atmosphere of $80 \% \mathrm{~N}_{2}-20 \% \mathrm{CO}_{2}$ is shown in Fig. 2. Acetate was stoichiometrically converted to methane (inset, Fig. 2) with a ratio of $0.97 \mathrm{~mol}$ of methane formed per mol of acetate consumed. Rates of methane production and acetate consumption were the same (maximum of $4.3 \mathrm{mmol}$ $1^{-1}$ day $^{-1}$ ). Due to different lag phases in replicate vials methane production curves are inadequate to demonstrate inhibitory or stimulating effects on the conversion of acetate to methane. Methanogenic activity was defined, therefore, in terms of a specific methane production rate $\left(\mu_{\mathrm{CH}_{4}}\right)$ which was calculated from the linear part of a half-logarithmic graph $\left(\mathrm{CH}_{4}\right.$ vs. time). The exponential methane production in Fig. 2 yielded for instance a $\mu_{\mathrm{CH}_{4}}$ of $0.205 \mathrm{day}^{-1}$ or a "doubling time" $t_{d\left(\mathrm{CH}_{4}\right)}$ of 3.4 days.

\section{Growth Conditions}

Table 1 shows the effect of the cations $\mathrm{K}^{+}, \mathrm{Na}^{+}$and $\mathrm{Ca}^{2+}$ which were added as acetate salts. Concentrations of $50 \mathrm{mmol} / 1$ induced almost the same methane production rate as found in the controls with only $10 \mathrm{mmol} / \mathrm{l}$ sodium acetate or glacial acetic acid. Clarified rumen fluid $(20 \%$, vol $/ \mathrm{vol})$ or digested sludge supernatant $(20 \%$, vol/vol $)$ were of no significant effect on the rate of methane formation from acetate (Table 1). However, a reduced lag phase was observed (Huser 1981). Conversion of acetate to methane was not stimulated by yeast extract $(6 \mathrm{~g} / \mathrm{l})$ (Table 1$)$.

Temperature and $\mathrm{pH}$-relationships in growing cultures of $M$. soehngenii are shown in Figs. 3 and 4. The optimal temperature was $37^{\circ} \mathrm{C}$. At $50^{\circ} \mathrm{C}$ neither growth nor methane formation occurred and a subsequent incubation at $37^{\circ} \mathrm{C}$ could not restore the activity. However, at low temperatures $\left(3^{\circ} \mathrm{C}\right)$ growth and methane production took place at a much reduced rate which increased when the cultures were brought back to $37^{\circ} \mathrm{C}$. Between $10^{\circ}$ and $37^{\circ} \mathrm{C}$ the temperature dependence of methane production from acetate followed the Arrhenius-relationship $\left(\theta^{10}=2.05\right.$; inset, Fig. 3).

Methane formation occurred within a range of $\mathrm{pH} 6.8-$ 8.2. The optimum was at $\mathrm{pH} 7.4-7.8$ (Fig. 4). 


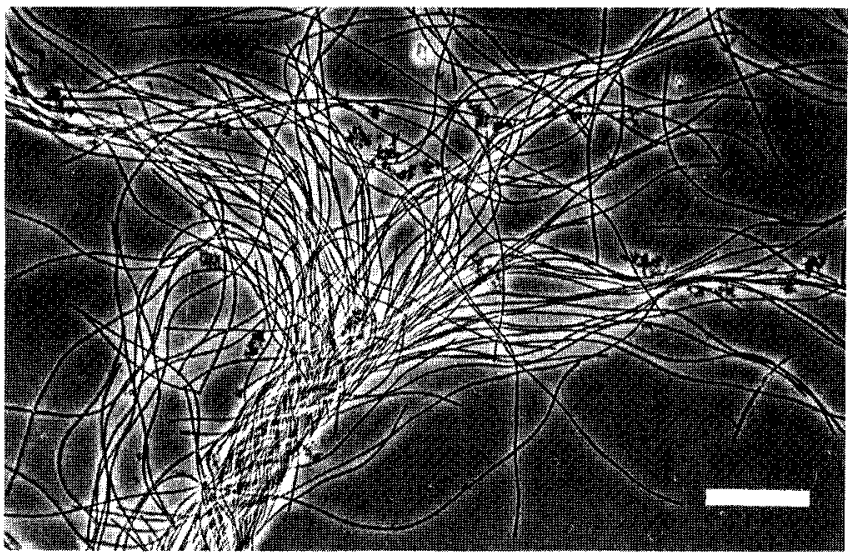

Fig. 1. Phase contrast photomicrograph of Methanothrix soehngenii showing the growth in long filaments which form characteristic bundles, bar indicates $50 \mu \mathrm{m}$

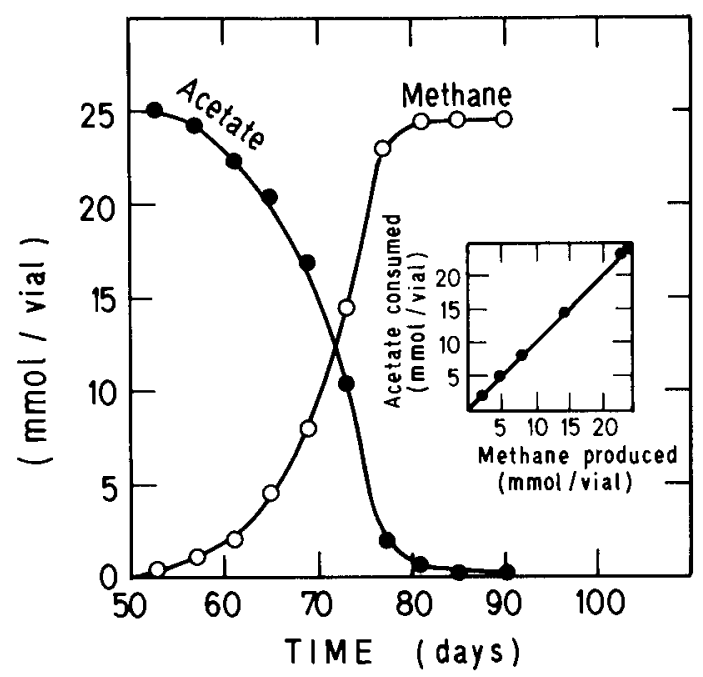

Fig. 2. Acetate conversion to methane during growth of Methanothrix soehngenii on acetate $(50 \mathrm{mmol} / \mathrm{l})$ in a batch culture with $500 \mathrm{ml}$ MSmedium (Inoculum $0.5 \mathrm{ml}$ )

Table 1. Specific methane production rate $\left(\mu_{\mathrm{CH}_{4}}\right)$ for Methanothrix soehngenii under various growth conditions

\begin{tabular}{ll}
\hline Medium and growth condition & $\begin{array}{l}\mu_{\mathrm{CH}_{4}}{ }^{\mathrm{c}} \\
\left(\text { days }^{-1}\right)\end{array}$ \\
\hline $\mathrm{MS}^{\mathrm{a}}+$ sodium acetate $(10 \mathrm{mM})$ & 0.157 \\
$\mathrm{MS}+$ glacial acetic acid $(10 \mathrm{mM})$ & 0.164 \\
$\mathrm{MS}+$ sodium acetate $(50 \mathrm{mM})$ & 0.168 \\
$\mathrm{MS}+$ potassium acetate $(50 \mathrm{mM})$ & 0.158 \\
$\mathrm{MS}+$ calcium acetate $(50 \mathrm{mM})$ & 0.154 \\
$\mathrm{MS}^{\mathrm{b}}+$ clarified rumen fluid $(20 \%$, vol $/ \mathrm{vol})$ & 0.181 \\
$\mathrm{MS}^{\mathbf{b}}+$ digested sewage supernatant $(20 \%$ vol/vol) & 0.191 \\
$\mathrm{MS}^{\mathrm{b}}+$ yeast extract $(6 \mathrm{~g} / \mathrm{l})$ & 0.153 \\
$\mathrm{MS}+$ sodium acetate $(50 \mathrm{mM})$, shaking $(100 \mathrm{rpm})$ & 0.125
\end{tabular}

a Experiments were performed in batch cultures with $500 \mathrm{ml}$ MSmedium plus the indicated supplements

b MS incl. $10 \mathrm{mM}$ sodium acetate

- Mean value of duplicates

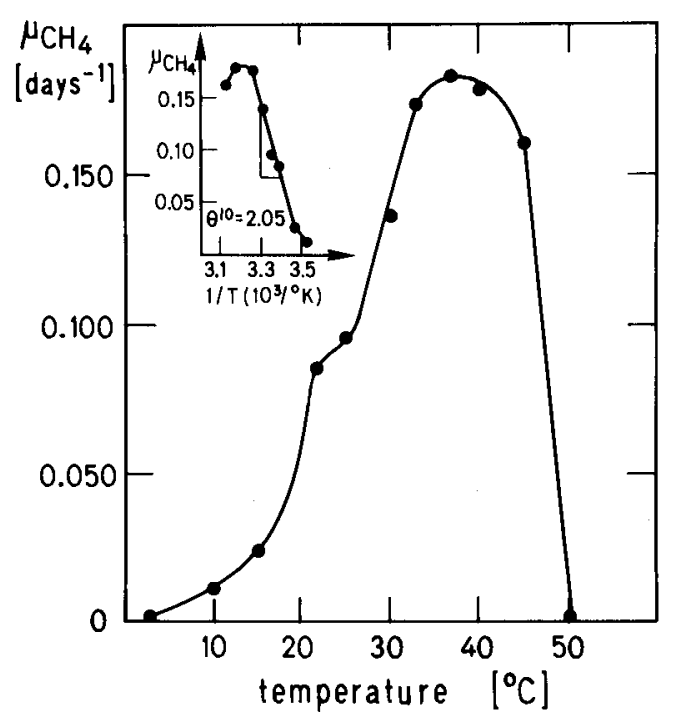

Fig. 3. Temperature-dependence of methane production from acetate by Methanothrix soehngenii. The data represent mean values with standard deviation from triplicates. Inset: Arrhenius-equation of temperaturedependence

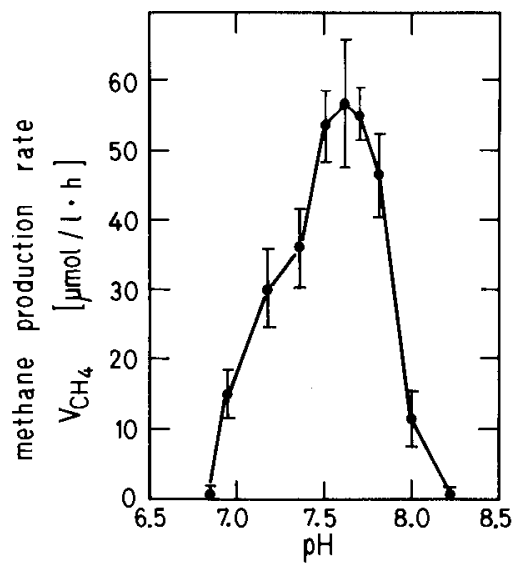

Fig. 4. Effect of $\mathrm{pH}$ on the methane production rate $\left(v_{\mathrm{CH}_{4}}\right)$ from acetate. The results are averages of a minimum of two replicates. Bars indicate standard deviation

Effect of Oxygen. M. soehngenii could be enriched not only from several sewage digesters but also from aerobic samples of pretreated raw sewage (Huser 1981). This suggested an oxygen tolerance of the organism. Replicate cultures were gassed with pure oxygen $(0.2,1,6,48 \mathrm{~h})$. Aliquots $(5 \mathrm{ml})$ were then centrifuged $(3000 \times \mathrm{g}, 15 \mathrm{~min})$ and resuspended in $50 \mathrm{ml}$ MS-medium. Untreated cell suspensions $(5 \mathrm{ml})$ inoculated in $50 \mathrm{ml}$ MS-medium served as controls. After variable lag phases (few hours to 3 days) the cultures, initially gassed with oxygen, and the ungassed controls showed similar rates of methane production. Microscopic examination did not reveal any lysed cells.

\section{Substrates for Growth and Methane Formation}

Some details on the metabolism of $M$. soehngenii have already been published in our earlier paper (Zehnder et al. 1980). Besides acetate no other methanogenic substrate $\left(\mathrm{H}_{2}-\mathrm{CO}_{2}\right.$, 


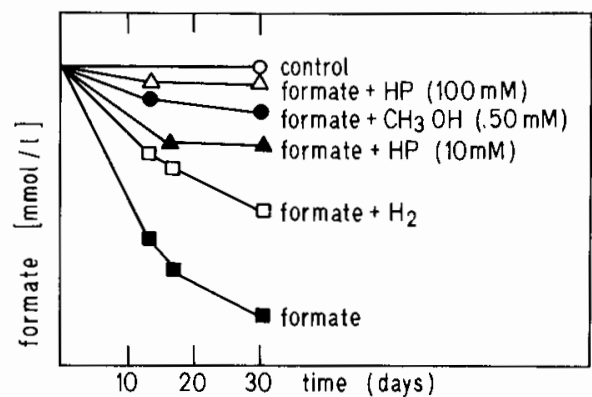

Fig. 5. The cleavage of formate under various experimental conditions. Heat treated cells $\left(90^{\circ} \mathrm{C}, 10 \mathrm{~min}\right)$ served as controls. $H P$ Hypophosphite

methanol, methylamines, formate) could serve for growth and methane formation. Formate was split into equal amounts of hydrogen and carbon dioxide which, however, were not utilized as substrates (results not shown). Adaptation to utilize hydrogen is unlikely, since cultures of $M$. soehngenii showed no consumption of hydrogen when incubated for over 6 months with a gas phase of $\mathrm{H}_{2} / \mathrm{CO}_{2}$ $(80 / 20 \%)$ in the presence of acetate.

Methanol $(50 \mathrm{mmol} / \mathrm{l})$ and hydrogen (gasphase $80 \% \mathrm{H}_{2}$ $-20 \% \mathrm{CO}_{2}$ ) inhibited the formate cleaving system (Fig. 5). Hypophosphite, a selective inhibitor of formate dehydrogenase (Takamiya 1942), causes a concentration-dependent inhibition of the formate splitting activity. The presence of a formate dehydrogenase in $M$. soehngenii is strongly suggested by these observations. Interestingly enough hypophosphite $(100 \mathrm{mmol} / \mathrm{l})$ inhibited also the conversion of acetate to methane and carbon dioxide (results not shown). A variety of compounds (propionate, butyrate, pyruvate, citrate, glucose, glycerine; each at $10 \mathrm{mmol} / \mathrm{l}$ ) were assayed in presence and without acetate for their ability to serve as sole or as cosubstrate for growth and/or methanogenesis. Methane formation and growth was exclusively observed in presence of acetate. The same was true in experiments with the following acetylated and/or methylated compounds (each at $10 \mathrm{mmol} / \mathrm{l}$ ): dimethylsulfide, dimethylsulfoxide, acetoacetate, phenylacetate, $\mathrm{N}, \mathrm{N}$-dimethylformamide, $\mathrm{N}$-methylacetamide, $\mathrm{N}, \mathrm{N}$-dimethylacetamide, $\mathrm{N}$-acetylglucosamine, methanosulfonic acid, 2-acetylbenzoic acid, 2-methoxyethanol, acetone, trimethylphosphate, acetaldehyde, formaldehyde. The last two substances caused a total inhibition of acetate conversion. Nitrate and sulfate were not utilized with acetate as an electron donor.

\section{Inhibitors and Antibiotics}

The effect of some known inhibitors of methanogenesis on $M$. soehngenii was studied in the MS-medium inoculated with $20 \%(\mathrm{vol} / \mathrm{vol})$ of an actively growing culture. Complete inhibition was caused by methylviologen $(5 \mu \mathrm{mol} / \mathrm{l})$, benzylviologen $(5 \mu \mathrm{mol} / \mathrm{l})$, chloroform $(20 \mu \mathrm{mol} / 1)$, sodium arsenate $(100 \mu \mathrm{mol} / \mathrm{l})$ and potassium cyanide $(100 \mu \mathrm{mol} / \mathrm{l})$. The effect of fluoroacetate, nitrate and iodopropane is shown in Fig. 6. Iodopropane $(0.1 \mathrm{mmol} / \mathrm{l})$ completely suppressed methanogenesis from acetate. Fluoroacetate resulted in a concentration-dependent inhibition of methane formation. Trifluoroacetate (in a concentration range of $0.1-2 \mathrm{mmol} / \mathrm{l}$ ) had no effect (results not shown). Methanogenesis from $\mathrm{H}_{2}$ $-\mathrm{CO}_{2}$ is inhibited by 2-bromoethanesulfonic acid (2-BES), an analogue of coenzyme M (2-mercaptoethanesulfonic acid;

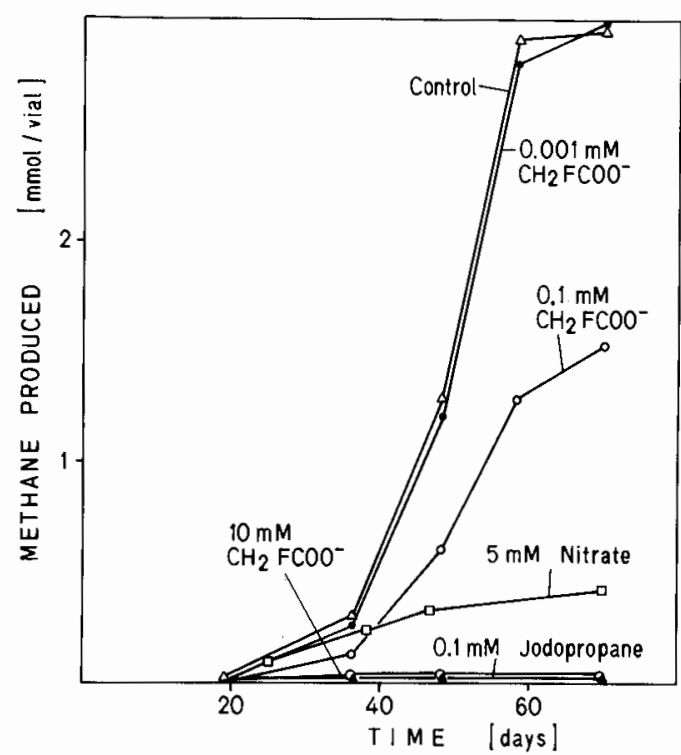

Fig. 6. Effect of inhibitors on methane formation from acetate. Vials containing $50 \mathrm{ml} \mathrm{MS}$-medium were inoculated $(2 \%$, vol $/ \mathrm{vol})$. Values of two replicate cultures were averaged (standard deviation $<5 \%$ ). Vials without any inhibitors served as controls

Balch and Wolfe 1979; Gunsalus 1977). It was shown to inhibit acetate conversion to methane in cultures of Methanosarcina strain 227 (Smith and Mah 1978) and M. soehngenii (Zehnder and Brock 1979) as well. The inhibition with 2-BES is relieved by addition of coenzyme $M$ in Methanosarcina strain 227 (Smith and Mah 1978). This did not occur, however, with $M$. soehngenii, even with a 50 -fold excess of coenzyme $M$.

Growing cultures of $M$. soehngenii were tested for their sensitivity to some known antibiotics in liquid media. It is known that methanogenic bacteria are insensitive to some antibiotics which act against eubacteria (Hammes et al. 1979; Hilpert et al. 1981). This fact has already been exploited for the selective enrichment and isolation of methanogens (Godsy 1980; Zinder and Mah 1979). The antibiotics examined in our work, together with their effects are listed in Table 2. Dihydrostreptomycin and novobiocin were chosen as a proof of the effectiveness of the experimental procedure. Since vancomycin (at $0.1 \mathrm{mg} / \mathrm{ml}$ ) showed no negative effect on growth and methanogenesis ist was routinely added to the MS-medium for subculturing and maintenance of $M$. soehngenii.

\section{Kinetic Data on Methanogenesis from Acetate}

Most of the kinetic data reported earlier for methanogenesis from acetate are of limited value because they were obtained from complex ecosystems (Kaspar and Wuhrmann 1978; Smith and Mah 1966) or from enrichment cultures (Lawrence and McCarty 1969). The only kinetic studies on acetate conversion to methane with pure cultures are those with Methanosarcina strain 227 (Smith and Mah 1978).

The methane production rate of $M$. soehngenii gets concentration-dependent at an acetate level of less than $10 \mathrm{mmol} / 1$ (Fig. 7). A " $K_{s}$ "-value of $0.7 \pm 0.05 \mathrm{mmol} / 1$ has been calculated for methanogenesis from acetate (concentration range $1-50 \mathrm{mmol} / \mathrm{l}$ ). In the course of a batchexperiment the methane production rate was comparable to 
Table 2. Effect of some antibiotics on the growth of Methanothrix soehngenii

\begin{tabular}{lccrl}
\hline Antibiotic & \multicolumn{3}{l}{ Concentrations $(\mathrm{mg} / \mathrm{ml})$} \\
\cline { 2 - 5 } & 0.01 & 0.1 & 1.0 & 10.0 \\
\hline Penicillin-G & $15^{\mathrm{a}}$ & 80 & 88 & 100 \\
Ampicillin & 0 & 55 & 98 & 100 \\
D-cycloserine & 0 & 40 & 100 & n.m. \\
Vancomycin & $\mathrm{n} . \mathrm{m}$. & 0 & 88 & 100 \\
Novobiocin & 67 & 75 & 97 & 100 \\
Dihydrostreptomycin & 97 & 100 & 100 & n.m. \\
\hline
\end{tabular}

a Percent inhibition of growth. Values of controls after 4 weeks incubation were taken as zero percent inhibition, based on dry weight determinations

b n. m. not measured

the acetate consumption rate. In the initial phase (less than $5 \%$ acetate utilized), however, the acetate consumption rate was significantly greater than the corresponding methane production rate (Fig. 8, Fig. 2). This was true for all acetate concentrations assayed in the range of $0.1-50 \mathrm{mmol} / \mathrm{l}$. Specific metabolic rates of $k_{\mathrm{Ac}}=1.62 \pm 0.1 \mathrm{mmol} \mathrm{g}^{-1} \mathrm{~h}^{-1}$ and $k_{\mathrm{CH}_{4}}=1.46 \pm 0.1 \mathrm{mmol} \mathrm{g}^{-1} \mathrm{~h}^{-1}$ were calculated from triplicate determinations.

\section{Deoxyribonucleic Acid Base Composition (Mol Percent Guanine Plus Cytosine)}

The mol percent $\mathrm{G}+\mathrm{C}$ was calculated to be $51.9 \%$ for $M$. soehngenii.

\section{Discussion}

The physiological and morphological characteristics of the new methane bacterium resemble those of the filamentous organism first reported by Söhngen (1906). The same type of bacterium was later observed by various other investigators in their cultures with acetate as sole energy substrate (Barker 1936; Groenewege 1920; Mylroie and Hungate 1954; Smit 1930) or in enrichment cultures on various substrates with acetate as a free intermediate e. g. on propionate (Boone and Bryant 1980), on butyrate, (Mclnerney et al. 1979), on benzoate (Ferry and Wolfe 1976), on cellulose (Khan and Mes-Hartree 1981) or on lignin derivatives (Healy et al. 1980). A similar organism was recently described in a highly enriched culture (Colvin et al. 1979; van den Berg et al. 1976). However, its isolation was never successful. We have cultured Methanothrix soehngenii with more than 20 transfers in a mineral salt medium with acetate as the sole organic carbon compound. No requirement for a growth factor developed within this period. Growth on acetate exhibited exponential kinetics. Thus, the splitting of acetate into methane and carbon dioxide apparently generated sufficient energy for growth. Our finding that no other substrates (e.g. $\mathrm{H}_{2}$, propionate, butyrate, pyruvate, citrate, glucose, glycerine) were cometabolized, excluded the need for supplementary energy sources for growth and/or methanogenesis from acetate contrary to reports from other authors (Toerien et al. 1971; Zeikus et al. 1975).

Methane Formation. The mechanism by which methane is formed from acetate and the concomitant energy generating

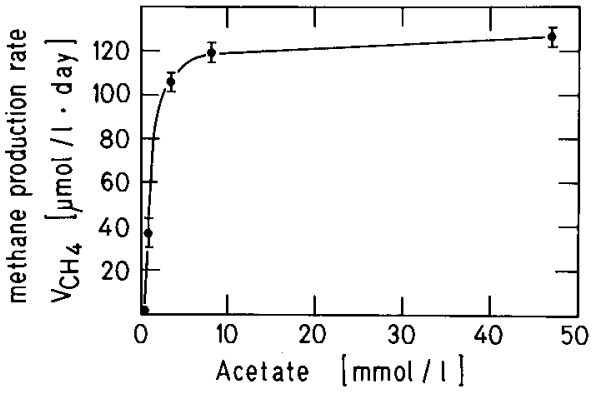

Fig. 7. Methane production rate $\left(v_{\mathrm{CH}_{4}}\right)$ at different acetate concentrations $(0.1-50 \mathrm{mmol} / \mathrm{l})$. Duplicate values were averaged and are given with the standard deviation

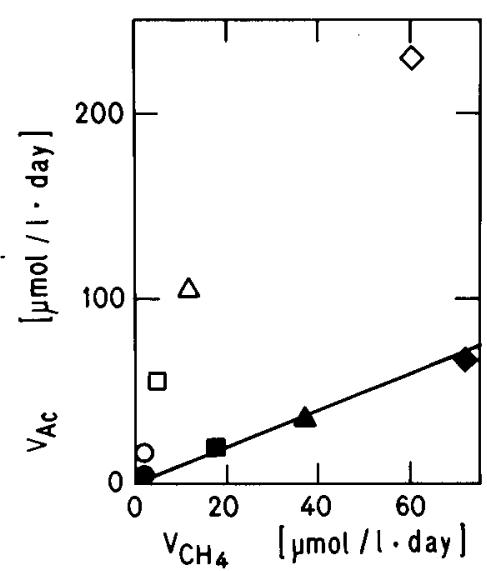

Fig. 8. Rates of acetate consumption ( $\left.v_{\mathrm{Ac}}\right)$ and methane production $\left(v_{\mathrm{CH}_{4}}\right)$ in batch experiments with the following initial acetate concentrations $(\mathrm{mM}): 0.2(\bullet, 0), 0.5(\mathbf{\square}, \square), 1.0(\boldsymbol{\wedge}, \Delta), 2.0(\bullet, \diamond)$. Open signs represent datas obtained at an early phase of the experiment (less than $5 \%$ of the added acetate consumed). Closed symbols show data obtained later ( $10-$ $15 \%$ acetate consumed). The line indicates the theoretical value of $v_{\mathrm{Ac}} / v_{\mathbf{C H}_{\mathbf{4}}}=1$

system are not known. The inhibition of the acetate conversion to methane by known inhibitors of the hydrogenotrophic methanogenesis, e.g. 2-bromoethanesulfonic acid, viologen dyes, $\mathrm{CHCl}_{3}$ (Balch and Wolfe 1979; Gunsalus 1977; McBride and Wolfe 1971; Roberton and Wolfe 1970) suggests a similarity of the mechanisms for methane production from acetate and from $\mathrm{H}_{2}-\mathrm{CO}_{2}$. The inhibitory effect of 2-bromoethanesulfonic acid is of particular interest in view of the fact that coenzyme $M$ is involved in the methylreductase system in hydrogenotrophic (Gunsalus and Wolfe 1980) as well as in acetotrophic methanogenesis (Baresi and Wolfe 1981). Labeling experiments with cultures of $M$. soehngenii clearly demonstrated that the methyl group of acetate was converted to methane and the carboxyl group to carbon dioxide (Huser 1981; Zehnder et al. 1980), in analogy to the acetate conversion by Methanosarcina species (Mah et al. 1978; Smith et al. 1980; Zinder and Mah 1979).

The efficiency of energy generation estimated by the molar growth yields on acetate is similar in $M$. soehngenii and in Methanosarcina barkeri. Values ( $\mathrm{g}$ biomass per mol acetate utilized) of 1.1 (Hutten et al. 1981), 1.8 - 2.7 (Smith and Mah 1978), 1.6-1.9 (Weimer and Zeikus 1978) and 2.1 (Zinder and Mah 1979) were reported for Methanosarcina species, compared to $1.1-1.4$ for $M$. soehngenii and 1.1 for a similar 
organism in a enrichment culture (van den Berg et al. 1976). This does not mean, however, that the mechanism of acetate conversion to methane is the same in both organisms. Growth of Methanosarcina is concentration-dependent at acetate concentrations of less than $50 \mathrm{mmol} / 1$, reflecting the relatively high $K_{s}$-value ( $5 \mathrm{mmol} / 1$; Smith and Mah 1978).

Extrapolation to lower acetate concentrations $(<3 \mathrm{mM})$ resulted in specific growth rates comparable to those of $M$. soehngenii at these acetate concentrations. The low $K_{\mathrm{s}}$-value for the conversion of acetate to methane by $M$. soehngenii $(0.7 \mathrm{mmol} / \mathrm{l})$, which is in the concentration range of the optimum of the functioning of sewage digesters (Kaspar and Wuhrmann 1978; Cappenberg 1976) may be one reason for the successful competition of $M$. soehngenii in various ecosystems. Methanosarcina is usually not present in great amounts in digested sludge (Mah et al. 1978; Pretorius 1972; van den Berg et al. 1976; Wolfe 1971; own observations) or in freshwater sediments (Winfrey and Zeikus 1979; own observations). The presence, however, of Methanothrix in all of nine municipal sewage digesters observed in Switzerland and in the USA, in mechanically pretreated raw sewage, in a sanitary landfill and in various Indian biogas plants fed on cattle manure or nightsoil (Huser 1981; unpublished observations), indicate its wide distribution in nature as possibly the major acetate-utilizing methanogen (McInerney et al. 1981).

Taxonomy. The lack of murein in the cell envelope of $M$. soehngenii and the presence of ether-linked polyisoprenoid alcohols clearly characterize the newly isolated organism as an archaebacterium (Woese 1981). Methane formation, and the presence of the unique coenzyme CoM classify the bacterium as a methanogen. Morphological and physiological features are similar to organisms first described by Söhngen (1906) and later named Methanobacterium soehngenii in an impure culture by Barker (1936). However, the morphology and ultrastructure (Huser 1981; Zehnder et al. 1980), the absence of a pseudomurein-type cell wall (Kandler and König, personal communication), the lack of $\mathrm{C}_{40^{-}}$ tetraethers as polar lipids (Langworthy, personal communication) and, most conclusive, the comparative cataloging of the 16S rRNA (Stackebrandt et al. 1982), clearly show that it does not belong to the order Methanobacteriales. A new genus Methanothrix within the order Methanomicrobiales (Balch et al. 1979) was therefore proposed (Stackebrandt et al. 1982; Zehnder et al. 1980).

\section{Description}

Methanothrix soehngenii gen. nov. et sp. nov. Me.tha'no.thrix. M.L.n. methanum methane; Gr.n.thrix hair; M.L. fem.m. Methanothrix the methane (-producing) hair, soehn'gen.i.i., M.L.gen.n. soehngenii of Söhngen; named in honor of N.L. Söhngen who in 1906 first described a similar organism converting acetate to methane.

A combined generic and specific description follows.

\section{Morphology}

The non-sporeforming cells are rodshaped with flat ends occurring as long filaments in unshaken cultures. The Gram reaction is negative. The outer layer of the cell wall is composed of proteins (O. Kandler and $\mathrm{H}$. König, personal communication). It has a sheath-like structure which shows a regular striation. Cells are non-motile.

\section{Cell Wall}

The unstable cell wall is devoid of muramic acid (O. Kandler, personal communication).

\section{Lipids}

Di-o-phytanyl glycerol ether $\left(\mathrm{C}_{20}\right)$ was found as the only polar lipid. Tetraether $\left(\mathrm{C}_{40}\right)$ and phosphoglycolipids are absent (T. Langworthy, personal communication).

\section{Nutrition}

Anaerobic. Grows chemoorganotrophically in a defined mineral salt medium that contains vitamins, trace metals and acetate as the only organic component. Other organic supplements are not required. Methane is exclusively formed from the methyl group of acetate. $\mathrm{H}_{2}-\mathrm{CO}_{2}$, formate, methanol and methylamines cannot be used for growth or methane formation. Formate is split into hydrogen and carbon dioxide. Acetate and carbon dioxide are assimilated.

\section{Growth Characteristics}

The organism grows at temperatures between $3^{\circ}$ and $45^{\circ} \mathrm{C}$ with an optimum at $37^{\circ} \mathrm{C}$, and at $\mathrm{pH}$ values between 6.8 and 8.2 , with optimum growth between $\mathrm{pH} 7.4-7.8$.

\section{Oxygen Tolerance}

Exposure to oxygen has no lethal effect. Growth and methane formation occurs, however, only under strictly anaerobic and highly reducing conditions.

\section{Biochemical Features}

Coenzyme $\mathrm{M}(0.35 \mathrm{nmol} / \mathrm{mg}$ dry cells $)$ and $F_{420}(0.55 \mu \mathrm{g} / \mathrm{mg}$ protein) were determined in cell extracts. Two different types of membrane-bound cytochromes were found (W. Kühn, personal communication).

\section{DNA Base Composition}

The $\mathrm{G}+\mathrm{C}$ content of the DNA is 51.9 moles $\%$.

\section{Phylogenetic Relationship}

Comparative analysis of the $16 \mathrm{~S}$ rRNA revealed only a distant relationship to other methanogens. The highest degree of relatedness was found to Methanosarcina barkeri $\left(\mathrm{S}_{\mathrm{AB}}=0.44\right)$.

\section{Habitat}

Methanothrix soehngenii was isolated from digested sewage sludge. Enrichments were obtained from all of nine examined sewage digesters for domestic wastes, from biogas fermenters for animal wastes, from a sanitary landfill and from mechanically pretreated raw sewage. It was not found in enrichments from anoxic freshwater sediments. 


\section{Type Strain}

The type strain of Methanothrix soehngenii is strain Opfikon. The description of the type strain is identical to that of the species. This strain has been deposited in the German Collection of Microorganisms (DSM) under the number 2139.

Acknowledgements. We thank O. Kandler, W. Kühn, and T. A. Langworthy for generously providing unpublished data. We gratefully acknowledge the help of $\mathrm{E}$. Stackebrandt in the determination of the $\mathrm{G}+\mathrm{C}$-content of the DNA. We are indebted to $\mathrm{H}$. Trüper for the critical review of the generic and specific name we proposed.

\section{References}

Balch WE, Wolfe RS (1976) New approach to the cultivation of methanogenic bacteria: 2-mercaptoethanesulfonic acid (HS-CoM)dependent growth of Methanobacterium ruminantium in a pressurized atmosphere. Appl Environ Microbiol 32:781 - 791

Balch WE, Wolfe RS (1979) Specifity and biological distribution of coenzyme M (2-mercaptoethanesulfonic acid). J Bacteriol $137: 256-263$

Balch WE, Fox GE, Magrum LJ, Woese CR, Wolfe RS (1979) Methanogens: Reevaluation of a unique biological group. Microbiol Rev 43:260-296

Baresi L, Wolfe RS (1981) Levels of coenzyme $F_{420}$, coenzyme M, hydrogenase, and methylcoenzyme $M$ methylreductase in acetategrown Methanosarcina. Appl Environ Microbiol 41:388 - 391

Barker HA (1936) Studies upon the methane-producing bacteria. Arch Mikrobiol 7:420-438

Belyaev SS, Finkel'shtein ZI, Ivanov MV (1975) Intensity of bacterial methane formation in ooze deposits of certain lakes. Microbiology $44: 272-275$

Boone DR, Bryant MP (1980) Propionate-degrading bacterium, Synthrophobacter wolinii, sp. nov. gen. nov., from methanogenic ecosystems. Appl Environ Microbiol 40:626-632

Bryant MP (1972) Commentary on the Hungate technique for culture of anaerobic bacteria. Am J Clin Nutr 25:1324-1328

Buswell AM, Hatfield WD (1936) Anaerobic fermentations. Ill State Wat Survey Bull 32:59-65

Cappenberg TE (1976) Methanogenesis in the bottom deposits of a small stratified lake, in: HG Schlegel, G Gottschalk, N Pfennig (eds) Microbial formation and utilization of gases $\left(\mathrm{H}_{2}, \mathrm{CH}_{4}, \mathrm{CO}\right)$. Verlag Goltze KG, Göttingen, pp 125-134

Cappenberg TE, Prins H (1974) Interrelations between sulfate-reducing and methane-producing bacteria in bottom deposits of a fresh water lake. III. Experiments with ${ }^{14} \mathrm{C}$-labelled substrates. Antonie van Leeuwenhoek J Microbiol Serol 40:457-469

Colvin JR, Sowden LC, van den Berg L (1979) The ultrastructure of the major species of an enriched methanogenic culture utilizing acetic acid. Can J Microbiol 25:826-832

Ferry JG, Wolfe RS (1976) Anaerobic degradation of benzoate to methane by a microbial consortium. Arch Microbiol 107:33 - 40

Godsy EM (1980) Isolation of Methanobacterium bryantii from a deep aquifier by using a novel broth-antibiotic disc method. Appl Environ Microbiol 39:1074-1075

Groenewege J (1920) Bakteriologische Untersuchungen über biologische Reinigung. Med Burg Geneesk Dienst 1:67-125

Gunsalus RP (1977) The methyl-coenzyme M reductase system in Methanobacterium thermoautotrophicum. Thesis, University of Illinois, Urbana-Champaign

Gunsalus RP, Wolfe RS (1980) Methyl coenzyme M reductase from Methanobacterium thermoautotrophicum. J Biol Chem 255:18911895

Hammes WP, Winter J, Kandler O (1979) The sensitivity of the pseudomurein-containing genus Methanobacterium to inhibitors of murein synthesis. Arch Microbiol 123:275-279

Healy JB, Young LY, Reinhard M (1980) Methanogenic decomposition of ferulic acid, a model lignin derivative. Appl Environ Microbiol $39: 436-444$
Hilpert R, Winter J, Hammes WP, Kandler O (1981) Sensitivity of archaebacteria to antibiotics. Zbl Bakt 1. Abt Orig C 2:11-21

Holdemann LV, Moore WEC (ed) (1972) Anaerobe laboratory manual. Virginia Polytechnic Institute and State University, Blacksburg

Hoppe-Seyler F (1876) Über die Processe der Gährungen und ihre Beziehung zum Leben der Organismen. Pflügers Arch ges Physiol $12: 1-17$

Hungate RE (1950) The anaerobic mesophilic cellulolytic bacteria. Bacteriol Rev 14:1-49

Huser BA (1981) Methanbildung aus Acetat: Isolierung eines neuen Archaebakteriums. Thesis Nr. 6750, Swiss Federal Institute of Technology, Zürich

Hutten TJ, de Jong MH, Peeters BPH, van der Drift Ch, Vogels GD (1981) Coenzyme $M$ derivatives and their effects on methane formation from carbon dioxide and methanol by cell extracts of Methanosarcina barkeri. J Bacteriol 145:27-34

Jeris JS, McCarty PL (1965) The biochemistry of methane fermentation using $\mathrm{C}^{14}$ tracers. J Wat Poll Contr Fed 37:178-192

Kaspar HF, Wuhrmann K (1978) Kinetic parameters and relative turnovers of some important catabolic reactions in digesting sludge. Appl Environ Microbiol 36:1-7

Khan AW, Mes-Hartree M (1981) Metabolism of acetate and hydrogen by a mixed population of anaerobes capable of converting cellulose to methane. J Appl Bacteriol 50:283-288

Lawrence AW, McCarty PL (1969) Kinetics of methane fermentation in anaerobic treatment. J Wat Poll Cont Fed 41:1-17

Mackie RI, Bryant MP (1981) Metabolic activity of fatty acid-oxidizing bacteria and the contribution of acetate, propionate, butyrate, and $\mathrm{CO}_{2}$ to methanogenesis in cattle waste at 40 and $60^{\circ} \mathrm{C}$. Appl Environ Microbiol $41: 1363-1373$

Mah RA, Hungate RE, Ohwaki K (1976) Acetate, a key intermediate in methanogenesis, in: HG Schlegel, J Barnea (eds) Microbial energy conversion. E. Goltze KG, Göttingen, pp 97-106

Mah RA, Smith MR, Baresi L (1978) Studies on an acetate-fermenting strain of Methanosarcina. Appl. Environ Microbiol 35:11741184

McBride BC, Wolfe RS (1971) A new coenzyme of methyl-transfer, coenzyme M. Biochem 10:2317-2324

McInerney MJ, Bryant MP, Pfennig N (1979) Anaerobic bacterium that degrades fatty acids in syntrophic association with methanogens. Arch Microbiol 122:129-135

McInerney MJ, Mackie RI, Bryant MP (1981) Syntrophic association of a butyrate-degrading bacterium and Methanosarcina enriched from bovine rumen fluid. Appl Environ Microbiol 41:826-828

Mountfort DO, Asher RA (1978) Changes in proportions of acetate and carbon dioxide used as methane precursors during the anaerobic digestion of bovine waste. Appl Environ Microbiol 35:648-654

Mylroie RL, Hungate RE (1954) Experiments on the methane bacteria in sludge. Can J Microbiol 1:55-64

Pretorius WA (1972) The effect of formate on the growth of acetate utilizing methanogenic bacteria. Wat Res 6:1213-1217

Roberton AM, Wolfe RS (1970) Adenosine triphosphate pools in Methanobacterium. J Bacteriol 102:43-51

Schnellen CGTP (1947) Onderzoekingen over de Methaangisting. Proefschrift, Technische Hoogeschool, Delft

Smit J (1930) Die Gärungssarcinen. Eine Monographie. Pflanzenforschung 14:1-59

Smith PH (1966) The microbial ecology of sludge methanogenesis. Devel Ind Microbiol 7:156-161

Smith PH, Mah RA (1966) Kinetics of acetate metabolism during sludge digestion. Appl Microbiol 14:368-371

Smith MR, Mah RA (1978) Growth and methanogenesis by Methanosarcina strain 227 on acetate and methanol. Appl Environ Microbiol 36:870-879

Smith MR, Zinder SH, Mah RA (1980) Microbial methanogenesis from acetate. Process Biochem 15:34-39

Söhngen NL (1906) Het ontstaan en verdwijnen van waterstof en methaan onder den invloed van het organische leven. Proefschrift. Technische Hoogeschool, Delft

Stackebrandt E, Kandler O (1979) Taxonomy of the genus Cellulomonas based on phenotypic characters and deoxyribonucleic acid- 
deoxyribonucleic acid homology, and proposal of seven neotype strains. Int J Syst Bacteriol 29:273-282

Stackebrandt E, Seewaldt E, Ludwig W, Schleifer K-H, Huser BA (1982) Classification of Methanothrix soehngenii, a new methanogenic archaebacterium. Zbl Bakt Hyg 1. Abt Orig C, in press

Takai Y (1970) The mechanism of methane fermentation in flooded paddy soil. Soil Sci Plant Nutr 16:238-244

Takai Y, Koyama T, Kamura T. (1963) Microbial metabolism in reduction process of paddy soils. Soil Sci and Plant Nutr $9: 1-5$

Takamiya A (1942) Über die Formicodehydrase von Escherichia coli. Acta Phytochim 13:1-9

Toerien DF, Thiel PG, Pretorius WA (1971) Substrate flow in anaerobic digestion. Adv Wat Poll Res 11:II 29/1-29/7

van den Berg L, Patel GB, Clark DS, Lentz CP (1976) Factors affecting rate of methane formation from acetic acid by enriched methanogenic cultures. Can J Microbiol 22:1312-1319

Weimer PJ, Zeikus JG (1978) Acetate metabolism in Methanosarcina barkeri. Arch Microbiol 119:175-182

Winfrey MR, Zeikus JG (1979) Anaerobic metabolism of immediate methane precursors in Lake Mendota. Appl Environ Microbiol $37: 244-253$

Woese CR (1981) Archaebacteria. Scient Am 244:94-106
Wolfe RS (1971) Microbial formation of methane, in: AH Rose, JF Wilkinson (eds) Advances in microbiological physiology. Academic Press Inc., New York, vol 6, pp 107-146

Wolin EA, Wolin MJ, Wolfe RS (1963) Formation of methane by bacterial extracts. J Biol Chem 238:2882-2886

Zehnder AJB, Brock TD (1979) Methane formation and methane oxidation by methanogenic bacteria. J Bacteriol 137:420-432

Zehnder AJB, Huser B, Brock TD (1979) Measuring radioactive methane with the liquid scintillation counter. Appl Environ Microbiol $37: 897-899$

Zehnder AJB, Huser BA, Brock TD, Wuhrmann K (1980) Characterization of an acetate-decarboxylating, non-hydrogenoxidizing methane bacterium. Arch Microbiol 124:1-11

Zeikus JG, Weimer PJ, Nelson DR, Daniels L (1975) Bacterial methanogenesis: Acetate as a methane precursor in pure culture. Arch Microbiol 104:129-134

Zinder SH, Mah RA (1979) Isolation and characterization of a thermophilic strain of Methanosarcina unable to use $\mathrm{H}_{2}-\mathrm{CO}_{2}$ for methanogenesis. Appl Environ Microbiol 38:996-1008

Received January 19, 1982/Accepted February 26, 1982 